\title{
BLADE RUNNER W KOMBINACIE ZAKRZYWIONEJ CZASOPRZESTRZENI, CZYLI FILM RIDLEYA SCOTTA W POWIEŚCI SHŌNO YORIKO
}

\author{
BEATA KUBIAK HO-CHI ${ }^{1}$ \\ (Uniwersytet Warszawski)
}

\begin{abstract}
Słowa kluczowe: Blade Runner - Łowca androidów - Ridley Scott - Taimu surippu konbināto Shōno Yoriko - współczesna literatura japońska - science fiction

Key words: Blade Runner - Ridley Scott - Taimu surippu konbināto Shōno Yoriko - contemporary Japanese literature - science fiction
\end{abstract}

\begin{abstract}
Abstrakt: Beata Kubiak Ho-Chi. BLADE RUNNER W KOMBINACIE ZAKRZYWIONEJ CZASOPRZESTRZENI, CZYLI FILM RIDLEYA SCOTTA W POWIEŚCI SHŌNO YORIKO. PORÓWNANIA 18, 2016. T. XVIII. S. 183-196. ISSN 1733-165X. Blade Runner, tytuł kultowego filmu Ridleya Scotta z 1982 r., w Polsce znanego jako Łowca androidów, niczym wysłannik ponurej przyszłości pojawia się na kartach powieści „Kombinat zakrzywionej czasoprzestrzeni” (Taimu surippu konbināto, 1994), pióra współczesnej japońskiej pisarki Shōno Yoriko (ur. 1956). Co łączy te dwa utwory, należące przecież do różnych porządków narracyjnych - tak wizualnego, jak tekstowego? Co zainspirowało Shōno w Blade Runnerze i jakie są skutki tej inspiracji dla fabuły powieści? Na ile sajensfikcyjny, postapokaliptyczny świat słynnego filmu Ridleya Scotta przenika slipstreamową prozę Shōno Yoriko i kształtuje jej powieściową rzeczywistość? Oprócz odpowiedzi na te pytania, autorka niniejszego artykułu podejmuje również temat roli science fiction we współczesnej literaturze japońskiej oraz przedstawia sylwetkę i dorobek literacki Shōno Yoriko, pisarki wybitnej, lecz jak do tej pory z różnych powodów poza Japonią mało znanej.
\end{abstract}

Abstract: Beata Kubiak Ho-Chi. BLADE RUNNER IN THE TIME WARP COMPLEX: THE MOVIE BY RIDLEY SCOTT IN SHONO YORIKO'S NOVEL. COMPARISONS 18, 2016. Vol. XVIII. P. 183-196. ISSN 1733-165X. Blade Runner, the title of Ridley Scott's cult movie (1982), emerges on

${ }^{1}$ E-mail Address: kubiak@post.pl 
the pages of the novel Time Warp Complex (Taimu surippu konbināto, 1994) by Shōno Yoriko (b. 1956), a contemporary Japanese woman writer, as an envoy from the bleak future. What connects these two works belonging to different narrative forms, both visual and textual? What kind of inspiration does Shono draw from the Blade Runner and what are its implications for the novel's plot? To what extent does the post-apocalyptic, science-fictional world of Ridley Scott's movie permeate the slipstream literature of Shōno Yoriko, shaping its fictional reality? Apart from answering above questions, the author of the present article also considers the role of science-fiction in contemporary Japanese literature, along with presenting the profile and literary work of Shōno Yoriko, an outstanding woman writer - but so far, for various reasons, little known outside Japan.

Blade Runner, tytuł głośnego filmu Ridleya Scotta z 1982 roku², w Polsce znanego jako Łowca androidów $w^{3}$, jak zwiastun mrocznego ducha, wysłannik z ponurej przyszłości, która stała się już teraźniejszością, pojawia się na kartach powieści Taimu surippu konbināto (Kombinat zakrzywionej czasoprzestrzeni, 1994) autorstwa Shōno Yoriko (ur. 1956). Japońska pisarka otrzymała za nią prestiżową Nagrodę Akutagawy 4 dla początkujących pisarzy, będącą w Japonii przepustką do kręgów literackich. Co łączy te dwa utwory, należące do różnych porządków narracyjnych, wizualnego i tekstowego? Na czym polega inspiracja Shōno Blade Runnerem (Łowca androidów?) i jakie są jej skutki dla powieściowej fabuły. Na ile sajensfikcyjny, apokaliptyczny świat filmu amerykańskiego reżysera przenika halucynacyjną prozę Shōno i kształtuje jej powieściową rzeczywistość? Pytania te staną się w niniejszym artykule również pretekstem do refleksji nad rolą science fiction we współczesnej literaturze japońskiej, a także, a może przede wszystkim, do przedstawienia sylwetki i dorobku Shōno Yoriko, pisarki wybitnej, lecz do tej pory z różnych powodów poza Japonią mało znanej.

2 Scenariusz filmu został napisany przez Hamptona Fanchera i Davisa Peoplesa, a główne role grają Harrison Ford, Rutger Hauer, Sean Young i Edward James Olmos. Muzykę do filmu napisał John Vangelis.

${ }^{3} \mathrm{~W}$ artykule będę się posługiwała oryginalnym tytułem filmu, Blade Runner, gdyż w takiej właśnie wersji występuje on w powieści Shōno, tworząc skojarzenia, które polski tytuł nieco zaciera.

4 Pełna nazwa to Nagroda Akutagawy Ryūnosuke (jap. Akutagawa Ryūnosuke Shō). Została ustanowiona w 1935 roku przez Kikuchiego Kana, redaktora naczelnego czasopisma literackiego „Bungei Shunjū" na cześć pisarza Akutagawy Ryūnosuke (1892-1927). Przyznawana jest początkującym pisarzom, tworzącym literaturę wysoką artystycznie, dwa razy do roku i należy obecnie do najbardziej prestiżowych nagród literackich w Japonii. Do jej laureatów należą tacy wielcy japońscy pisarze, jak Abe Kōbō, Endō Shūsaku czy Ōe Kenzaburō. 


\section{Blade Runner - przepowiednia postindustrialnej dystopii}

Blade Runnera w zasadzie nie trzeba przedstawiać. Ten film science fiction, określany jako neo-noir, bądź tech-noir ${ }^{5}$, oparty na motywach powieści Philipa K. Dicka (1928-1982) Do androids dream of electric ships $(1968)^{6}$, został obwołany filmem kultowym i najlepszym $\mathrm{w}$ historii kina obrazem science fiction. Nie stało się to bezpośrednio po jego wejściu na ekrany, gdyż Blade Runner nie przyniósł sukcesu kasowego. Sławę osiągnął przede wszystkim dzięki rozwojowi kina domowego oraz wersjom na kasetach wideo i DVD z 1992 i 2007 roku7. Stał się również, jak pisze Nigel Wheale, „narodową instytucją”, należy bowiem do filmów zdeponowanych w Bibliotece Kongresu w Waszyngtonie z uwagi na ich wkład w rozwój sztuki filmowej ${ }^{8}$. Za efekty wizualne i scenografię, dla której szczególnie zasłużyli się dyrektorzy artystyczni filmu, David L. Snyder (ur. 1944) i Lawrence'a G. Paul (ur. 1938 ), oraz grafik-konceptualista Syd Mead (ur. 1933), Blade Runner był w 1982 roku nominowany do Oscara.

Tytuł filmu Scotta został zapożyczony z fantastyczno-naukowej powieści Williama Burroughsa Blade Runner (a movie) (1979) i nawiązuje do pojęcia z czasów wiktoriańskich, oznaczającego prywatnego detektywa (Wheale 107). Takim właśnie detektywem-policjantem, będącym $\mathrm{w}$ filmie amerykańskiego reżysera jednym z grupy blade runnerów, do zadań których należy eliminowanie androidów (nazywanych replikantami), jest Rick Deckard (grany przez Harrisona Forda). Ma on wytropić i unicestwić grupę replikantów Nexus 6, należących do najnowszej generacji. Dzięki inżynierii genetycznej replikanci z tej serii są praktycznie identyczni jak ludzie. Różni ich wyłącznie niezdolność do odczuwania i empatii, co może zostać wykryte jedynie dzięki skomplikowanemu testowi. Jego podstawą jest ana-

${ }^{5} \mathrm{Na}$ temat nurtu tech-noir, dla którego, oprócz Blade Runnera, reprezentatywne są takie filmy, jak na przykład Crash (Niebezpieczne pożądanie, 1996) D. Cronenberga czy The Terminator (Terminator, 1984) J. Camerona, zobacz więcej F. Botting. „Monsters of Imagination: Gothic, Science, Fiction”. A Companion to Science Fiction. Red. D. Seed. Malden (US), Oxford (UK): Blackwell Publishing, 2008. S. 121-124.

${ }^{6} \mathrm{Na}$ polski przełożony jako Blade Runner. Czy androidy marza o elektrycznych owcach? Tłum. S. Kędzierski. Poznań 2011. Scott pominął w swoim filmie ważny dla powieści Dicka etyczny temat zwierząt, jak również kult Wilberna Mercera, a skoncentrował się przede wszystkim na pościgu głównego bohatera za androidami.

7 Była to wersja reżyserska, director's cut, z 1992 r. i ostateczna wersja reżyserska, final cut, z 2007 r. Obie wersje są najbardziej zgodne z ostateczną wizją Scotta, który, przy kręceniu pierwszej wersji, w 1982 r. zmuszony był do wielu kompromisów ze względu na niewielki budżet i naciski ze strony producenta.

8 Por. N. Wheale. "Recognizing a "human-Thing": Cyborgs, Robots and Replicants in Philip K. Dick's Do Androids Dream of Electric Sheep? and Ridley Scott's Blade Runner. The Post-Modern Arts. Introductory Reader. Red. London: Routledge, 1995. S. 107. 
liza oka, które powinno odpowiednio reagować, gdy podejrzanej o bycie replikantem osobie zadawane są starannie opracowane pytania. Są one skonstruowane w taki sposób, by wywoływać u badanego silną reakcję emocjonalną - jej brak jest ewidentnym dowodem na przynależność do nie-ludzi. Replikanci wytwarzani są przez wielką i wpływową Korporację Tyrella oraz inne mega-korporacje na świecie, i wysyłani do pozaziemskich kolonii. Służą tam ludziom lub wykorzystywani są do wykonywania różnych niebezpiecznych prac. Są niemalże idealni, mają jednak wmontowane ograniczniki czasu życia, które pozwalają im egzystować jedynie przez cztery lata. Replikantom nie wolno przebywać na Ziemi, opuszczonej już przez większość ludzi9, ale kilku z nich, po wywołaniu w kosmicznej kolonii buntu, ignoruje zakaz i ucieka na Ziemię. Odnajdują tu i zabijają swojego twórcę oraz przywódcę Korporacji, Tyrella, gdyż nie potrafi on usunąć wbudowanego w ich ciała ogranicznika życia, które pragną przedłużyć. Fabuła filmu, dziejącego się w Los Angeles, w listopadzie 2019 roku, koncentruje się na pościgu Ricka Deckarda (Harrison Ford) za czterema ukrywającymi się w mieście replikantami. Pomimo niechęci do wykonania powierzonego mu zadania, Deckard postanawia podjąć się go po raz ostatni. Zabija wszystkich czterech replikantów i ucieka z asystentką Tyrella, piękną Rachael (Sean Young), która również okazała się replikantką ${ }^{10}$.

Siła Blade Runnera polegała na ukazaniu trafnej wizji przyszłości świata i ziemskiej cywilizacji. W chwili premiery filmu była ona jedynie ponurą przepowiednią postindustrialnej dystopii, natomiast dziesięć lat później, w czasach ukazania się jego wersji reżyserskiej, postapokaliptyczny fantazmat, przedstawiony w obrazie Scotta, przemówił mocą przepowiedni spełnionej ${ }^{11}$. Zniszczenie naturalnego środowiska, zagrożenie skażeniem atomowym, destrukcyjne działanie słońca, jak również nadmierny przyrost populacji, niekontrolowane migracje ludności, degradacja miast i zamieszkujących je ludzi - to tylko niektóre bolączki i lęki nękające współczesnego człowieka, żyjącego w stechnologizowanym, globalnym świecie, doskonale ukazanym w filmie Scotta.

${ }^{9} \mathrm{~W}$ filmie nie ma mowy o powodzie, dla którego ludzie opuścili Ziemię. Wiadomo o tym natomiast z powieści Dicka, gdzie powiedziane jest otwarcie, że ludzie zostali zdziesiątkowani w Ostatniej Wojnie Światowej, a ci, którzy przetrwali, wyemigrowali na Marsa. W wyniku wojny na Ziemię nieustannie spada radioaktywny pył, który sprawia, że panuje tu wieczny mrok. Z trudem przebijają się przez niego wątłe promienie słoneczne, a szkodliwy dla zdrowia, kwaśny deszcz nie przestaje padać. Wszystko to stało się powodem przenoszenia się ludzi na masową skalę do pozaziemskich kolonii. Zob. N.Wheale.

10 Zob. Blade Runner (The Director's Cut). Reż. R. Scott. Warner Home Video, 1997.

11 Zob. F. Caplan. “A Cult Classic Restored, Again”. The New York Times. 2007. Web. 30.09.2007. <http://www.nytimes.com/2007/09/30/movies/30kapl.html?_r=0> 


\section{Shōno Yoriko i „Kombinat zakrzywionej czasoprzestrzeni”}

To tę właśnie reżyserską wersję filmu, z 1992 roku, widziała najprawdopodobniej Shōno Yoriko, której powieść powstała dwa lata później. Film musiał wywrzeć na niej silne wrażenie, skoro cały „Kombinat zakrzywionej czasoprzestrzeni” przesiąknięty jest ciemną, psychodeliczną atmosferą, tak dobrze znaną z obrazu Scotta i docenioną $w$ powieści Shōno przez japońskich krytyków. Nie jest to pierwszy uznany utwór tej pisarki. Już wcześniej Shōno została wyróżniona ważnymi nagrodami literackimi za powieści Gokuraku (Raj, 1981; Nagroda Gunzō르), Nani mo shite nai (Nic nie robię, 1991; Nagroda Nomy ${ }^{13}$ ) i Nihyakkaiki (Ceremonia buddyjska w dwieście lat po śmierci, 1994; Nagroda Mishimy ${ }^{14}$ ). A przyznanie jej wspomnianej już nagrody Akutagawy za „Kombinat...” sprawiło, że jako pierwsza osoba w historii współczesnej literatury japońskiej została uhonorowana trzema najważniejszymi nagrodami, noszącymi wspólną nazwę sankan ${ }^{15}$.

Shōno, tworząca w duchu literatury wysokiej artystycznie (junbungaku), uznawana jest za pisarkę postmodernistyczną, slipstreamową ${ }^{16}$ - łączącą w swojej prozie charakterystyczne dla tego nurtu elementy surrealizmu, realizmu magicznego i niepokojącej fantastyki. W jej utworach można również odnaleźć ślady stylu powieści o sobie (shishōsetsu; inaczej - watakushi shōsetsu), mającej w Japonii długą tradycję. Przesyca je przy tym slapstickowy humor i ironia, chroniące przed patosem i sentymentalizmem często odnajdywanym w shishōsetsu. Język powieści Shōno, do którego pisarka przywiązuje szczególną wagę, choć trudno go nazwać klasycznie pięknym, jest niezwykle wypracowany i wyrafinowany, pełen odnie-

12 Nagroda czasopisma literackiego „Gunzō" (Grupa), przyznawana od 1958 roku debiutującym pisarzom; pełna nazwa Nagroda Literacka Gunzō dla Debiutujących Pisarzy (Gunzō Shinjin Bungaku Shō). Nagroda przyznawana jest twórcą literatury wysokiej artystycznie.

13 Pełna nazwa to Nagroda Literacka Nomy dla Początkujących Pisarzy (Noma Bungei Shinjin Shō). Jest jedną z czterech nagród wydawnictwa Kōdansha (obok nagrody dla uznanych pisarzy, dla pisarzy literatury dla dzieci i debiutujących pisarzy literatury dla dzieci) i przyznawana jest od 1979 roku pisarzom literatury wysokiej artystycznie.

14 Pełna nazwa - Nagroda Mishimy Yukio (Mishima Yukio Shō). Nagroda ta utworzona została w 1988 roku przez dom wydawniczy Shinchōsha dla upamiętnienia pisarza Mishimy Yukio (19251970). Przyznawana jest początkującym pisarzom, tworzącym literaturę wysoką artystycznie.

15 Sankan, czyli "trzy korony”, są nagrodami dla początkujących pisarzy: Akutagawy, Nomy i Mishimy. Do chwili obecnej, oprócz Shōno, te trzy najważniejsze wyróżnienia skompletowała (w 2012 roku) jedynie pisarka Kashimada Maki (ur. 1976).

16 Zob. Tatsumi T. Nihon henryū bungaku. Slipstream Japan (Japońska literatura slipstreamowa. Slipstream Japan). Tōkyō: Shinchōsha, 1998. S. 212. Literatura slipstreamowa jest rodzajem literatury spekulatywnej, postmodernistycznej science fiction, będącej mieszaniną różnych gatunków. Termin ten został ukuty przez cyberpunkowego pisarza Bruce'a Sterlinga w 1989 r. Za pisarzy slipstreamowych uznaje się zwykle Kurta Vonneguta, Thomasa Pynchona, Kathy Acker, Jamesa Patrica Kelly'ego czy Johna Kessela. 
sień i skojarzeń. To w tym metaforycznym, eksperymentalnym języku kryje się tajemnica trudności przebicia się utworów Shōno poza Japonię. Ich tłumaczy onieśmiela bowiem złożoność intertekstu i wiążąca się z nim waga wielopoziomowych asocjacji.

Ta absolwentka Wydziału Prawa Uniwersytetu Ritsumeikan w Kioto (Ritsumeikan Daigaku Hōgakubu), pochodząca z Ise, gdzie została wychowana w konserwatywnej, tradycyjnej japońskiej rodzinie, zaczęła pisać w czasach szkolnych. Trzeba było jednak wielu trudów i wyrzeczeń, ucieczki od duchów przeszłości i nabrania wiary we własne siły, by ziściły się jej marzenia o zostaniu pisarką. Pomógł jej w tym wyjazd w 1985 roku do Tokio, w którego okolicach mieszka i tworzy już od trzydziestu lat (Shimizu 27-29). Po literackim sukcesie „Kombinatu...” nadszedł dla Shōno Yoriko najlepszy i najbardziej kreatywny okres, który w zasadzie trwa do tej pory. Ma ona na swoim koncie około trzydziestu powieści i co najmniej drugie tyle opowiadań, jak na przykład: Haha no hattatsu (Rozwój matki, 1996), Tōkyō yōkai fuyū (Fruwające duchy z Tokio, 1998)17, Yūkai Mori musume ibun (Dziwna opowieść o Mori - dziewczynie z tajemnego lasu, 2001; Nagroda Izumiego Kyōki ${ }^{18}$ ), Suishōnai seido (System kryształu, 2003; Nagroda Sense of Gender ${ }^{19}$ ), Konpira (Konpira, 2005; Nagroda Itō Sei ${ }^{20}$ ) i należąca do jej ostatnich prac powieść Mitōbyōki - kōgenbyō, "kongōsei ketsugō sōshikibyō"no Shōno Yoriko (Zapiski o nieuleczalnej chorobie Shōno Yoriko - kolagenozie, „mieszanej chorobie tkanki łącznej”, 2014; Nagroda Nomy). Ta ostatnia powieść, jak również wydane dziesięć lat wcześniej Aibetsu sotoneko zakki (Zapiski o kotach podwórkowych i bólu rozstania, 2005), są bliższe dokumentowi niż fikcji. W Mitōbyōki... Shōno, choć odcina się na wstępie od literatury faktu, wzruszająco, lecz jednocześnie rzeczowo, dzieli się z czytelnikami swoją wiedzą i refleksją na temat nieuleczalnej choroby immunologicznej, jaką wykryto u niej kilka lat temu21. Drugi utwór jest z kolei poświęcony

${ }^{17}$ Haha no hattatsu kandydowała do Nagrody Literackiej Murasaki Shikibu (Murasaki Shikibu Bungaku Shō), Tōkyō yōkai fuyū - do Nagrody Literatury Kobiecej (Joryū Bungaku Shō). Shōno wycofała jednak obie kandydatury, nie chcąc być utożsamianą z literaturą kobiecą i nagradzaną głównie dlatego, że jest kobietą.

18 Pełna nazwa to Nagroda Literacka Izumiego Kyōki (Izumi Kyōka Bungaku Shō). Nagroda ta przyznawana jest za wysoką artystycznie powieść lub dramat. Została ustanowiona w 1973 roku przez miasto Kanazawa, dla upamiętnienia setnej rocznicy urodzin pisarza Izumiego Kyōki (18731939).

${ }^{19}$ Japońska nazwa to Sensu obu Gendā Shō. Nagroda ta, ustanowiona przez Japońskie Stowarzyszenie Gender, Fantasy i Science Fiction (Jendā SF Kenkyūkai), przyznawana jest dorocznie, od 2001 roku, powieściom science fiction, fantasy, mandze i filmom, w których eksplorowany jest temat gender.

${ }^{20}$ Nagroda Literacka Itō Seia (Itō Sei Bungaku Shō) przyznawana jest od 1990 roku, w dziedzinie literatury i krytyki, przez miasto Otaru, dla uczczenia pamięci pisarza, poety i krytyka, Itō Seia.

${ }^{21}$ Zob. Shōno Y. Mitōbyōki - kōgenbyōo, "kongōsei ketsugō sōshikibyō" no Shōno Yoriko. Tōkyō: Gunzō, 2014. 
trudowi, jaki pisarka podjęła, aby ratować będące pod jej opieką bezpańskie koty $^{22}$. Zwierzęta te bardzo często pojawiają się $\mathrm{w}$ jej opowiadaniach i powieściach, których tematyka jest tak bogata, że trudno ją jednoznacznie określić. Niewątpliwie jednak, niezależnie od tego, czy Shōno pisze o samotnej kobiecie, matce, mieście, kotach czy sintoistyczno-buddyjskich bogach, jej proza, przesiąknięta egzystencjalistycznym poszukiwaniem własnego miejsca w postnowoczesnej rzeczywistości, jest przejawem szczególnego uwrażliwienia pisarki na problemy współczesnego, zglobalizowanego świata ${ }^{23}$.

Taki właśnie świat, chaotyczny, ponury i ubogi, odnajdujemy w „Kombinacie zakrzywionej czasoprzestrzeni”. Japoński tytuł Taimusurippu konbināto odsyła do dziedziny fantastyki i brzmi oryginalnie nawet w uszach Japończyka. „Taimusurippu" jest neologizmem utworzonym od angielskich słów "time” i "slip" na oznaczenie, przede wszystkim w science fiction, załamania czasoprzestrzennego (zwykle po japońsku określanego słowami jukū sakusō), natomiast konbināto pochodzi od rosyjskiego słowa „kombinat”, oznaczającego obiekt przemysłowy ${ }^{24}$.

Akcja „Kombinatu...”, powieści, w której rzeczywistość przenika się z surrealistycznym, sennym majaczeniem, rozgrywa się w Tokio, a jej czas, jak można wnioskować z powieściowej narracji i z faktów z życia Shōno, przypada na wczesne lata dziewięćdziesiąte XX wieku. Do Sawano (głównej bohaterki i narratorki w jednej osobie), która pisze, prawie nie wychodząc ze swego mieszkania na odległych peryferiach Tokio, dzwoni tajemniczy mężczyzna. Nalega, by pojechała na dziwną stację kolejową o nazwie Umishibaura, znajdującą się na przeciwległym krańcu miasta. Jest to końcowa stacja linii Tsurumi, gdzie po jednej stronie peronu jest morze, po drugiej - budynek z wejściem wyłącznie dla pracowników Tōshiby, fabryki sprzętu elektronicznego. Jak z humorem wyjaśnia narratorka, „istnieją zatem dwie możliwości opuszczenia peronu: można wskoczyć do morza, albo pokazać w recepcji Tōshiby przepustkę. Jednym słowem, jeśli ktoś niebędący rybą, wężem wodnym albo pracownikiem Tōshiby wysiądzie na tej stacji, nie pozostanie mu nic innego, jak tylko czekać, aż pociąg będzie wracał" (Shōno 2007: 9)25.

22 Shōno Y. Aibetsu sotoneko zakki. Tōkyō: Kawade Bunko, 2005.

${ }^{23}$ To dlatego, choć Shōno nie angażuje się aktywnie w ruchy społeczne czy polityczne, często powołują się na nią zarówno feministki, jak i przeciwnicy współczesnej japońskiej neoliberalnej gospodarki.

${ }^{24}$ Por. Takeuchi K. "Taimusurippu konbināto" + dokusha $=($ sōzō + rensō $) \times$ tawamure $=\infty$ ” (Kombinat zakrzywionej czasoprzestrzeni + czytelnik $=<$ wyobraźnia + skojarzenia $>\mathrm{x}$ zabawa $=\infty$ ). Gendai josei sakka dokuhon 4. Shōno Yoriko (Przewodnik po współczesnych japońskich pisarkach 4. Shōno Yoriko). Red. Shimizu Y. Tōkyō: Kanae Shobō, 2006. S. 58. W języku polskim „kombinat”, zwykle uzupełniony przydawką "przemysłowy”, ma to samo znaczenie, co w języku rosyjskim.

25 Shōno Y. "Taimu surippu konbināto". Shōno Yoriko. Sankan shōsetsushū (Zbiór trzech koronnych powieści Shōno Yoriko). Tōkyō: Kawade Shobō Shinsha, 2007. S. 9. 
Telefoniczny rozmówca prosi Sawano, by w takim właśnie miejscu zrobiła bliżej nieokreślone zdjęcia. Kobieta nie jest pewna ani tego, kim jest dzwoniący człowiek, ani nawet tego, czy sam telefon nie jest sennym majakiem:

W takie właśnie miejsce (do Umishibaury. B.K.) kazał mi jechać mój telefoniczny rozmówca, którego w żadnym razie nie byłam w stanie zidentyfikować. Przede wszystkim należy zacząć od tego, że kiedy z głębokiego snu wyrwał mnie dźwięk telefonu, pomyślałam sobie, że to też mi się śni. Powiedziałam "halooo" i kiedy przez pierwsze trzy sekundy trwała cisza, nabrałam przekonania, że to dzwoni Iks. Wydało mi się wtedy, że rozpoznaję jego głos. Pomyślałam więc, że śni mi się, że dzwoni Iks i tylko dlatego odpowiedziałam pewnym, spokojnym głosem: „Sawano, słucham, o co chodzi?" (Shōno 2007: 9)

Sawano jest sperturbowana, gdyż ostatecznie nie rozpoznaje dzwoniącego, ani nie domyśla się, w jakiej sprawie on dzwoni. Poza tym, wcześniej śniło jej się, że jest zakochana $w$ tuńczyku i miłość ta tak bardzo ją pochłonęła, iż $\mathrm{z}$ obawy, że przestanie czuć się zakochana, nie chce się obudzić. To dlatego na zadawane pytania odpowiada mechanicznie:

- Ummm, ...czyyy..., ummm..., czy była już pani uprzejma zastanowić się nad obietnicą?

- Tak, jak najbardziej - kontynuowałam automatycznie. Nie miałam oczywiście zielonego pojęcia, o czym on mówi. I nie chodziło nawet o to, że nie wiedziałam, co to była za obietnica - ja przede wszystkim nikomu niczego nie obiecywałam. A poza tym, byłam zaabsorbowana miłością do tuńczyka, choć działa się tylko we śnie. (Shōno 2007: 10)

W trakcie przedłużającej się rozmowy telefonicznej, mężczyzna rzuca mimochodem, zupełnie nie wdając się w szczegóły, że miejsce, do którego chciałby ją wysłać, Umishibaura, przypomina scenerię z Blade Runnera. Sawano zupełnie nie interesuje ani nic nie mówiąca jej nazwa stacji, ani robienie zdjęć. Podejrzewa jednak, że morze i chylące się ku upadkowi przemysłowe budynki, które widziała we śnie, to właśnie Umishibaura. Mając nadzieję, że spotka tam swego tuńczykakochanka, postanawia wyruszyć do Umishibaury. Na tym kończy się wstępna, najbardziej halucynacyjna część powieści, która następnie przechodzi w podróż bohaterki do Umishibaury, „pościg” za miłością, symbolizowaną przez wyśnionego tuńczyka. Podróż ta przypomina kluczenie po labiryncie. Po drodze Sawano musi się wielokrotnie przesiadać, nie obiera jednak standardowej trasy, lecz wydłuża drogę i jedzie pociągiem linii centralnej (Chūōsen), łączącej stację Shinjuku ze stacją Tokijską.

Zaburzona świadomość geograficzna miasta Tokio jest ważnym elementem powieści Shōno. Wszystko w jej narracji jest zaburzone, gdyż tokijski moloch jest dla Sawano stosunkowo nowym doświadczeniem, a linia Chūō, spinająca dwa krańce jego centralnej części, wydaje jej się bezpieczna. Choć więc podróż jest dla Sawano wielkim stresem i wzbudza w niej poczucie zagubienia, kobieta dzielnie 
przesiada się z pociągu w pociąg, kluczy po podziemnych przejściach, przedzierając się przez tę największą na świecie metropolię, jaką jest Tokio. Po drodze, w miarę oddalania się od centrum i zbliżania się do peryferii, na których znajduje się Umishibaura, widzi zmieniający się przemysłowy krajobraz. Poznaje na poziomie indywidualnego doświadczenia miasto, na które składają się fragmenty jego scenerii oraz wspomnień bohaterki $\mathrm{z}$ dawnych czasów. Są pomiędzy nimi wydarzenia z dzieciństwa i obraz kombinatu przemysłowego w portowym mieście Yokkaichi, gdzie się urodziła; jest morze, bliskie jej od dziecka, jest też Tokio, w którym kiedyś, w fabryce Tōshiby, pracowała jej matka. Czas i przestrzeń przenikają się i nakładają na siebie w tej chaotycznej relacji z podróży. Lata sześćdziesiąte, będące początkiem japońskiego wielkiego wzrostu gospodarczego, mieszają się z latami osiemdziesiątymi - okresem ekonomicznej bańki mydlanej i niewyobrażalnej prosperity oraz latami dziewięćdziesiątymi, które przyniosły krach ekonomiczny i głęboki kryzys wywołany pęknięciem bańki.

Po dojechaniu na miejsce, do Umishibaury, bohaterka rozpoznaje morze i przemysłowy krajobraz, który widziała we śnie. Nie odnajduje jednak ukochanego tuńczyka, który był dla niej osobiście jedynym celem podróży.

\section{Wizualna narracja w powieści Shōno a Blade Runner}

Powieściowa fabuła, w której czas nie płynie linearnie, a świadomość czasoprzestrzenna bohaterki jest zaburzona, nie jest łatwa do streszczenia. Jednym z tropów do odczytania powieści jest przyjrzenie się temu, co znajduje się poza fabułą, czyli w tym wypadku - przestrzeni narracyjnej zdominowanej przez afektywność, emotywność i wizualność. W kontekście filmu Blade Runner to przede wszystkim ten ostatni trop, wizualność - myślenie i przemawianie obrazami, będące z założenia podstawą ekspresji artystycznej medium filmowego, a nie powieściowego - wydaje się w utworze Shōno najważniejsze. „Kombinat...” jest właśnie zbiorem takich obrazów - przenikających się scenerii aktualnie przemierzanych miejsc, marzeń sennych i wspomnień. Przygnębiająca, depresyjna atmosfera utworu wynika przy tym nie tylko z plastycznej narracji słownej, lecz również z bezpośrednich odwołań do filmu. Blade Runner w powieści Shōno pojawia się kilkakrotnie26, bez komentarzy, zawsze w nawiązaniu do postindustrialnego, zniszczonego miejskiego krajobrazu Umishibaury i jej okolic: „Nie, nie o to chodzi, miejsce to

26 Przy zapisie w języku japońskim słów „blade runner” brak jest cudzysłowów, które wskazywałyby na to, że autorka ma na pewno na myśli tytuł filmu. Jest to jednak konwencja, jaką Shōno przyjęła również do zapisu innych tytułów, np. Hyokkori Hyotanjima (Tykwowa Wyspa), por. Shōno 2006: 18. Również kontekst sytuacyjny pozwala na jednoznaczne traktowanie Blade Runnera w powieści Shōno jako tytułu filmu i jednocześnie nastroju, z jakim ten film jest kojarzony. 
przypomina Blade Runnera" (Shōno 2007: 24) - wyjaśnia telefoniczny rozmówca, gdy Sawano dopytuje się o Umishibaurę. A gdy zastanawia się: „[C]zyżby Tōshiba miała jakiś związek z Blade Runnerem? Może tuńczyk jest replikantem, produkowanym w Tōshibie? To by znaczyło, że jest jak robot. Niee, to przecież blade runner jest replikantem...", i zadaje swemu rozmówcy pytanie: „Czy w Tōshibie produkują replikantów? I mój tuńczyk też został wyprodukowany w Tōshibie?" (Shōno 2007: 25), ten kategorycznie zaprzecza: „Nie, nie, nie, absolutnie nie! [...] To, że mówię o Blade Runnerze, nie oznacza, iż mam na myśli replikantów, chodzi mi o linię kolejową, - przecinającą miejsca, gdzie widać ślady dawnej ekspansji ekonomicznej" (Shōno 2007: 25).

Atmosfera, jaką wnosi do powieści Shōno sam tytuł filmu, Blade Runner, jest zasadnicza dla całości utworu japońskiej pisarki. Ponury, ciemny obraz Tokio, podobny do zniszczonego, postindustrialnego Los Angeles, znanego z filmu Scotta, gdzie "nowe” technologie i super "nowoczesna" architektura sprawiają wrażenie zniszczonych, upadłych „zrecyklowanych" 27 , odnajdujemy w opisach przemysłowej zony Umishibaury i jej okolic. Telefoniczny rozmówca opowiada o nich Sawano, kreśląc tło kryzysu, który doprowadził do upadku wielu przedsiębiorstw i zubożenia społeczeństwa:

W latach siedemdziesiątych był kryzys paliwowy, a potem te okolice jeszcze bardziej podupadły i opustoszały. W czasach ekonomii bańki mydlanej też nie było lepiej, podobnie jak z przedmieściami, miejskimi sypialniami - pozostały $\mathrm{w}$ nich tylko marne ślady czasów wielkiej prosperity. Sceneria jest interesująca z uwagi na swój futurystyczny wygląd, krajobraz z bliskiej przyszłości...., o, zupełnie jak świat Blade Runnera. Pojedziesz obejrzeć pozostałości snu o przemysłowej potędze, to, co pozostało, gdy wszystko się już skończyło. (Shōno 2007: 27)

A kiedy Sawano jedzie do Umishibaury, wbrew własnym chęciom, zobowiązana przez swego rozmówcę (podobnie jak do pościgu za replikantami zobowiązany został przez policję blade runner Deckard), z okien pociągu przejeżdżającego przez peryferie miasta, widzi szczegóły przydrożnego krajobrazu:

[...] Niewielkie budynki mieszkalne i potężne bloki; w oczy rzucają się głównie nazwy fabryk, firm, zakładów: Gare Ōmori Kōjō, Asahi Garasu, Asahi Danbōru.... I znów bloki, bloki, bloki - aż się człowiekowi robi niedobrze od bloków, „blokowe zmęczenie. (Shōno 2007: 41-42)

A gdy jest już bliżej docelowej stacji, „fabryczny” krajobraz potęguje się:

[...] prace konstrukcyjne i magazyny fabryki stali Nihon Kōkan. [...] Fabryki są tu olbrzymie, a małe statki pływają z dużą prędkością. Urodziłam się w Yokkaichi, wy-

27 Por. V. Sobchack, "American Science Fiction Film: An Overview”. A companion to Science Fiction. Red. D. Seed. Malden (US), Oxford (UK): Blackwell Publishing, 2008. S. 271. 
chowałam w Ise, zbyt blisko miałam do morza, żeby chodzić nad jego brzeg. Przez ile to już lat nie widziałam morza.... Lecz brzeg morski lubię, powinnam więc czuć się tu szczęśliwa, a jednak ten krajobraz w ogóle nie wprawia mnie w pogodny nastrój. [...] Przed stacją są tylko drzewa. Część terenu potężnej fabryki zajmują korty tenisowe. Fabryka Szkła Asahi Keihin - zdaje mi się, że nieraz widziałam szkło z Asahi. Po drugiej stronie kanału stoją cysterny z ropą. Czy to jest właśnie krajobraz z Blade Runnera? Ale to przecież nie Blade Runner, to kombinat. (Shōno 2007: 49)

Takich opisów jest w tekście dużo. Zniszczone budynki podupadających fabryk, brudne kanały, których wodę pokrywają plamy oleju, potężne, szare cysterny, opuszczone i zdewastowane magazyny, pokryte brunatną rdzą. Wszystkie te miejsca wywołują wspomnienia o minionych, dobrych czasach, kiedy kraj rozwijał się i ludzie mieli nadzieję na bogatą, dobrą przyszłość. Stacja Umishibaura, podobnie jak Los Angeles z Blade Runnera, są świadectwem pożegnania się człowieka ze snem o potędze.

Człowiek przyszłości z filmu Scotta i człowiek czasów współczesnych z powieści Shōno jest istotą zagubioną, niepewną, skazaną na błądzenie w świecie, w którym obiektywna rzeczywistość nie istnieje. Oczom nie można ufać - stąd tak dużo odniesień do oczu w Blade Runnerze. Kiedy przykładowo Deckard poddaje Rachael testowi, który wykaże, że kobieta nie jest człowiekiem, na ekranie widzimy źrenice replikantki. Razem z Deckardem staramy się śledzić wahania jej emocji, które mają zaświadczyć o umiejętności empatii. Oczy mają odzwierciedlić prawdę o Rachael, ukazać jej duszę. Ale jak tu mówić o prawdzie, skoro nawet nie jest pewne, czy sam Deckard nie jest replikantem ${ }^{28}$.

W powieści Shōno ta rozchwiana rzeczywistość i brak pewności, co jest prawdą, a co fałszem, wynika już z samych nakładających się na siebie obrazów snu i jawy. Nie wiadomo, kim tak naprawdę jest telefoniczny rozmówca Sawano, ani ona sama, ani tym bardziej jej kochanek-tuńczyk. Pomimo wyjątkowo dokładnego opisu postaci tuńczyka, ani czytelnik, ani narratorka nie wie, czy jest on rybą, cyborgiem czy może robotem?:

W rzeczywistości różnił się nieco od zwykłego tuńczyka, właściwie przypominał go tylko z kształtu. Jego ciało było na pewno rybie, lecz na szyi miał zwężenie, a jego źrenice były rozszerzone jak u pobudzonego kota. Sprawiało to, że oczy miał całkiem inne niż ryba. Jego skóra również bardziej przypominała srebrną i twardą skórę świeżo złowionego bonito niż tuńczyka. Był ode mnie nieco niższy, miał około stu sześćdziesięciu centymetrów wzrostu. Taki właśnie tunczyk pokazywał mi swe małe, podłużne płetwy, unosząc je lekko jak skrzydła pingwina i podwijając w górę ich czubki, niczym dekoracyjna roślina. Patrzył w moim kierunku, skręcając w lewo twarz w kształcie odwróconego trójkąta, umieszczoną z przodu i podobną do ludzkiej. Trochę się zmiesza-

\footnotetext{
${ }^{28}$ Reżyserska wersja filmu sugeruje, że tak właśnie jest - Deckard również jest replikantem.
} 
łam - przecież mój kot codziennie jadł karmę z tuńczyka. To pewnie dlatego od tej chwili zaczęłam o nim myśleć nie jak o tuńczyku, ale jak o człowieku-rybie. (Shōno 2007: 11-12)

Sawano, niczym blade runner, samotnie przemierza Tokio w pogoni za... cyberkochankiem?, zooandroidem? - bo jakimi "prawdziwymi” słowami należy określić tunczyka? W przeciwieństwie jednak do filmowego bohatera, kobieta chce dotrzeć do kogoś, kogo kocha, do obiektu swojej miłości, choć zna go tylko ze snu. Nie chce go wyeliminować, lecz nie dowierzając własnym zmysłom, chce sprawdzić, czy jest rzeczywisty (tym bardziej, że czasami podejrzewa, iż jej rozmówca jest tuńczykiem). Czym jednak w ogóle jest rzeczywistość, i czy jest możliwa w ponowoczesnym świecie, w którym wszystko jest symulakrem, złudnym obrazem bez oryginału? Ponowoczesność dotknięta jest entropią rzeczywistości rządzonej przez chaos i coraz mniej dla człowieka zrozumiałej29. Sawano nie odnajdzie w Umishibaurze swej idealnej miłości, ukażą jej się tylko w powietrzu gigantyczne gałki oczne tunczyka, mające kilka metrów obwodu (Shōno 2007: 62). Ale nie będą to oczy jej ukochanego. W dodatku będą one jeszcze bardziej nierealne od niego samego.

Wątków łączących „Kombinat...” z Blade Runnerem jest wiele. Oprócz tematu degradacji środowiska i przestrzeni życiowej człowieka, w obu utworach podjęty został także ważny w XXI wieku temat pamięci. Wiąże się on ze wspomnianą już niemożnością doświadczania obiektywnej rzeczywistości w rządzonym przez technologie współczesnym świecie. Asystentce Rachael, której pamięć spreparowano, wmontowano „prawdziwe” wspomnienia z dzieciństwa (należące do siostrzenicy Tyrella), konstruując całkowicie sztucznie jej tożsamość. Odpowiednikiem tego wątku w powieści Shōno jest zaburzona przez sen pamięć głównej bohaterki, powodująca chaos myśli, splątanie i zagubienie, tak często odczuwane i bolesne dla współczesnego człowieka.

Wielowymiarowe nawiązania w powieści Shōno do filmu Ridleya są nie tylko świadectwem oczywistego wrażenia, jakie zrobił na japońskiej pisarce Blade Runner, lecz potwierdzają również ważność i rosnący wpływ na współczesną literaturę gatunku science fiction, do niedawna jeszcze niedocenianego przez pisarzy tworzących literaturę wysoką. Lata dziewięćdziesiąte $X X$ wieku, jak pisze najbardziej uznany w Japonii badacz tego gatunku, Tatsumi Takayuki (ur. 1955) ${ }^{30}$, przyniosły

29 Por. J. Szmyd. Odczytywanie wspótczesności. Perspektywa antropologiczna, etyczna, edukacyjna. Kraków: Oficyna Wydawnicza AFM, 2011. S. 305; por. też Z. Bauman. Globalizacja i co z tego dla ludzi wynika. Tłum. Ewa Klekot. Warszawa: Panstwowy Insytut Wydawniczy, 2000.

${ }^{30}$ Tatsumi Takayuki jest literaturoznawcą i amerykanistą, autorem wielu artykułów i książek na temat literatury SF, w których zajmuje się zarówno historią rodzimej SF jak i komparatystyką. Zob. m.in. wspomnianą już Nihon henryū bungaku, w której analizuje utwory takich m.in. twórców, jak Tsutsui Yasutaka, Terayama Shūji, Shōno Yoriko, Murakami Haruki i in., czy Full Metal Apache. Tran- 
literaturę slipstreamową, która „dekonstruuje granice pomiędzy literaturą mainstreamową a literaturą science fiction" (Tatsumi 2008: 330). Prekursorem tego nurtu jest w Japonii pisarz pierwszej generacji rodzimej SF, Tsutsui Yasutaka. To właśnie w latach dziewięćdziesiątych wielu uznanych japońskich pisarzy, zaliczanych do twórców literatury junbungaku, zaczęło inkorporować do swoich slipstreamowych utworów elementy science fiction, bądź realizmu magicznego. Do takich pisarzy Tatsumi zalicza Murakamiego Harukiego (ur. 1949), Murakamiego Ryū (ur. 1952), Shimadę Masahiko (ur. 1961), Hisamę Jugiego (ur. 1927), Matsuurę Rieko (ur. 1958) i bohaterkę niniejszego artykułu, Shōno Yoriko. Nawet laureat Nagrody Nobla, Ōe Kenzaburō (ur. 1935), opublikował w 1990 roku sajensfikcyjną powieść Chiryōtō (Wieża uzdrowienia), w której zacierają się granice pomiędzy literaturą o wysokich walorach artystycznych a literaturą popularną (Tatsumi 2008: 330) ${ }^{31}$. W rezultacie rozprzestrzeniania się science fiction dzięki mediom gatunek ten wnika coraz głębiej do japońskiej literatury sleapstreamowej, która z kolei wpływa na oryginalność i wzbogaca japońską literaturę jako taką.

Blade Runner w „Kombinacie zakrzywionej czasoprzestrzeni” jest przykładem takiego właśnie mariażu, w którym literatura wysoka, dzięki subtelnej ingerencji fantastyki naukowej, jest w stanie podjąć na nowo tematy nurtujące człowieka XXI wieku.

\section{BIBLIOGRAFIA}

Bauman, Zygmunt. Globalizacja i co z tego dla ludzi wynika. Tłum. Ewa Klekot. Warszawa: Państwowy Insytut Wydawniczy, 2000.

Botting, Fred. „Monsters of Imagination: Gothic, Science, Fiction”. A Companion to Science Fiction. Red. D. Seed. Malden (US), Oxford (UK): Blackwell Publishing, 2008. S. 111-126.

Dick, Philip K. Blade Runner. Czy androidy marza o elektrycznych owcach. Tłum. Sławomir Kędzierski. Poznań: Rebis, 2011.

Shimizu, Yoshinori. Shōno Yoriko. Kokū no senshi (Shōno Yoriko, wojowniczka pustki). Tōkyō: Kawade Shobō Shinsha, 2002.

Sobchack, Vivian. "American Science Fiction Film: An Overview". A companion to Science Fiction. Red. D. Seed. Malden (US), Oxford (UK): Blackwell Publishing, 2008. S. 261-274.

Shōno, Yoriko. Aibetsu sotoneko zakki (Zapiski o podwórkowych kotach i bólu rozstania). Tōkyō: Kawade Bunko, 2005.

Shōno, Yoriko. Mitōbyōki - kōgenbyō, "kongōsei ketsugō sōshikibyō" no Shōno Yoriko (Zapiski o nieuleczalnej chorobie Shōno Yoriko - kolagenozie, „mieszanej chorobie tkanki łącznej”). Tōkyō: Gunzō, 2014.

sactions between Cyberpunk Japan and Avant-Pop America. Durham and London: Duke University Press, 2006, gdzie zastanawia się nad przenikaniem się sztuki różnych twórców SF, pisarzy, poetów, reżyserów, autorów anime i mangi, muzyków i performerów po obu stronach Pacyfiku.

31 Tatsumi zauważa w niej wyraźne inspiracje Arthurem C. Clarke'iem, Stanisławem Lemem i braćmi Sturgatskymi. 
Shōno, Yoriko. "Taimu surippu konbināto". Shōno Yoriko. Sankan shōsetsushū (Zbiór trzech koronnych powieści Shōno Yoriko). Tōkyō: Kawade Shobō Shinsha, 2007.

Szmyd, Jan. Odczytywanie wspótczesności. Perspektywa antropologiczna, etyczna, edukacyjna. Kraków: Oficyna Wydawnicza AFM, 2011.

Takeuchi, Kayo. „Taimusurippu konbināto” + dokusha $=($ sōzō + rensō $) \times$ tawamure $=\infty$ (Kombinat zakrzywionej czasoprzestrzeni + czytelnik $=<$ wyobraźnia + skojarzenia $>$ x zabawa $=\infty)$. Gendai josei sakka dokuhon 4. Shōno Yoriko (Przewodnik po współczesnych japońskich pisarkach 4. Shōno Yoriko). Red. Shimizu Y. Tōkyō: Kanae Shobō. 2006.

Tatsumi, Takayuki. Full Metal Apache. Transactions between Cyberpunk Japan and Avant-Pop America. Durham and London: Duke University Press, 2006.

Tatsumi, Takayuki. “Japanese and Asian Science Fiction”. A Companion to Science Fiction. Red. D. Seed. Malden (US), Oxford (UK): Blackwell Publishing, 2008. S. 323-336.

Tatsumi, Takayuki. Nihon henryū bungaku. Slipstream Japan (Japońska literatura slipstreamowa. Slipstream Japan). Tōkyō: Shinchōsha, 1998.

Wheale, Nigel. "Recognizing a "human-Thing": Cyborgs, Robots and Replicants in Philip K. Dick's Do Androids Dream of Electric Sheep? and Ridley Scott's Blade Runner". The Post-Modern Arts. Introductory Reader. Red. N. Wheale. London: Routledge, 1995. S. 101-111.

\section{Filmografia}

Blade Runner (The Director's Cut). Reż. R. Scott. Warner Home Video, 1997.

\section{Źródło elektroniczne}

Caplan, Fred. "A Cult Classic Restored, Again". The New York Times. 2007. Web. 30.09.2007. <http://www. nytimes.com/2007/09/30/movies/30kapl.html?_r=0> 